\title{
Análise do Conjunto Histórico do Hospital Psiquiátrico São Pedro (HPSP)
}

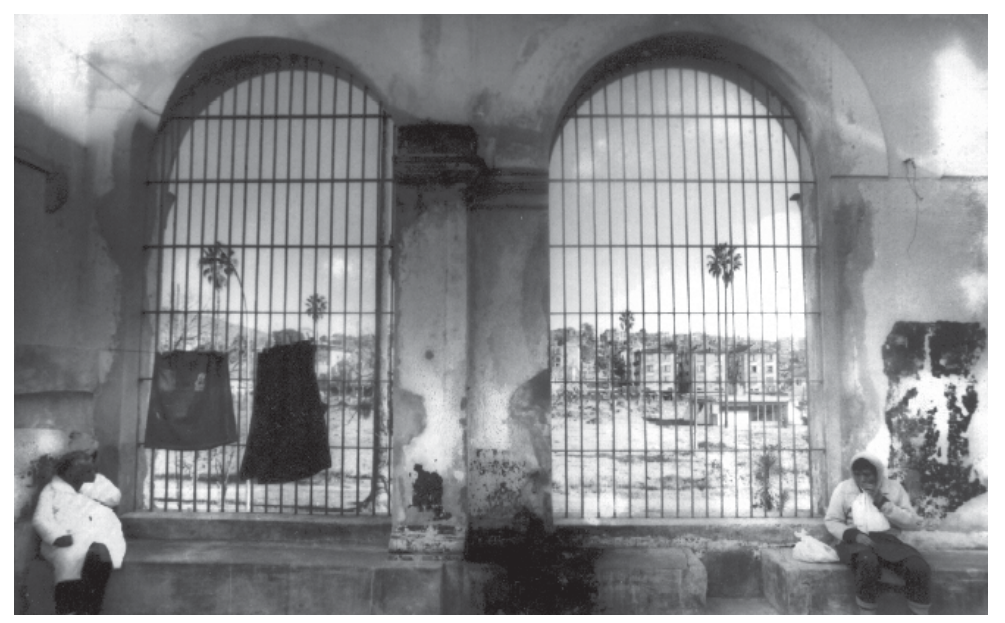

O Conjunto Histórico do Hospital Psiquiátrico São Pedro, cuja gleba original era de 33 hectares, constitui-se hoje numa área de 13,9 hectares, frente à Av. Bento Gonçalves, no bairro Partenon, centro geográfico da cidade de Porto Alegre. Os 19,1 hectares subtraídos ao longo de seus 122 anos de história e que representam $48 \%$ de sua área total dão lugar, hoje, a instituições públicas e privadas.

Esse magnífico conjunto compreende cerca de 40 edificações, perfazendo um total aproximado de $44.000 \mathrm{~m}^{2}$ de área construída, e tem como bem de maior relevância o Prédio Centenário.

Essa edificação, construída entre 1884 e 1903, é composta por seis corpos de dois pavimentos e porão, interligados transversalmente por um extenso eixo de circulação, gerando cinco pátios internos, numa estrutura tipo "pente", decorrente da adoção do "panóptico", modelo utilizado no século XIX para patrulhamento de grandes contingentes humanos, como prisões e internatos. O prédio recebeu, desde 1927, várias obras de remodelação e reformas sem critérios de intervenção, que não chegaram a descaracterizar o todo, constituindo-se, até hoje, no maior legado arquitetônico do final do século XIX em nosso estado.
A partir dos anos 50, tem-se a gradativa desocupação do Prédio Centenário para fins de moradia de pacientes, até chegarmos à situação atual, em que boa parte de sua área permanece desocupada ou com utilização informal. Atualmente, encontra-se em avançado estado de deterioração, apresentando infiltrações em vários pontos da cobertura, alvenarias com desabamentos, ataque generalizado de cupins, presença de fungos, descolamento de pintura e reboco, entre outras várias patologias comuns a prédios históricos em estado de abandono.

O Prédio Centenário foi tombado, juntamente com seu entorno, em nível estadual em 1990 e em nível municipal em 1993, obtendo suas áreas frontal e lateral sudeste gravadas como praça pelo Conselho Municipal de Desenvolvimento Urbano Ambiental em 2002.

O generoso espaço do Hospital Psiquiátrico São Pedro passa ao visitante uma sensação de caos e perplexidade. Essa sensação é potencializada pela dificuldade na leitura de suas estruturas referenciais, conseqüência da precária ordenação de fluxos e hierarquia de seus espaços e da implantação aleatória, ao longo do tempo, de prédios de baixa qualidade arquitetônica, sem um planejamento global. Um 
elemento de exceção na desordenação espacial do conjunto é o vazio frontal existente junto à avenida Bento Gonçalves. Esse vazio permite o distanciamento necessário à visualização do Prédio Centenário, colocando-o em posição privilegiada na paisagem urbana, causando sensação de respeito a esse magnífico exemplar arquitetônico, elemento marcante no imaginário coletivo de nossa cidade.

A despeito da localização favorecida e de sua magnitude, o Conjunto Histórico do HPSP nos remete à idéia de uma cidade da exclusão ou da loucura, com uma organização espacial tão peculiar quanto hermética. Se o objetivo é incluir, reabilitar e reciclar usos num futuro próximo, faz-se necessária a criação de pontos de diálogo entre as cidades intra e extramuros, que poderão surgir a partir da compreensão global do conjunto e da valorização de seu elemento referencial principal, o Prédio Centenário.

Renata Galbinski Horowitz

Designer, arquiteta da Divisão de Prédios Históricos da Secretaria de Estado das Obras Públicas e Saneamento, coordenadora técnica do Escritório de Restauração e Reciclagem do Conjunto Histórico do Hospital Psiquiátrico São Pedro / UERGS-SES-SOPS

Copyright (c) Revista de Psiquiatria do Rio Grande do Sul - SPRS 